\title{
Prevalence of skin diseases among students with disabilities in Mansoura, Egypt
}

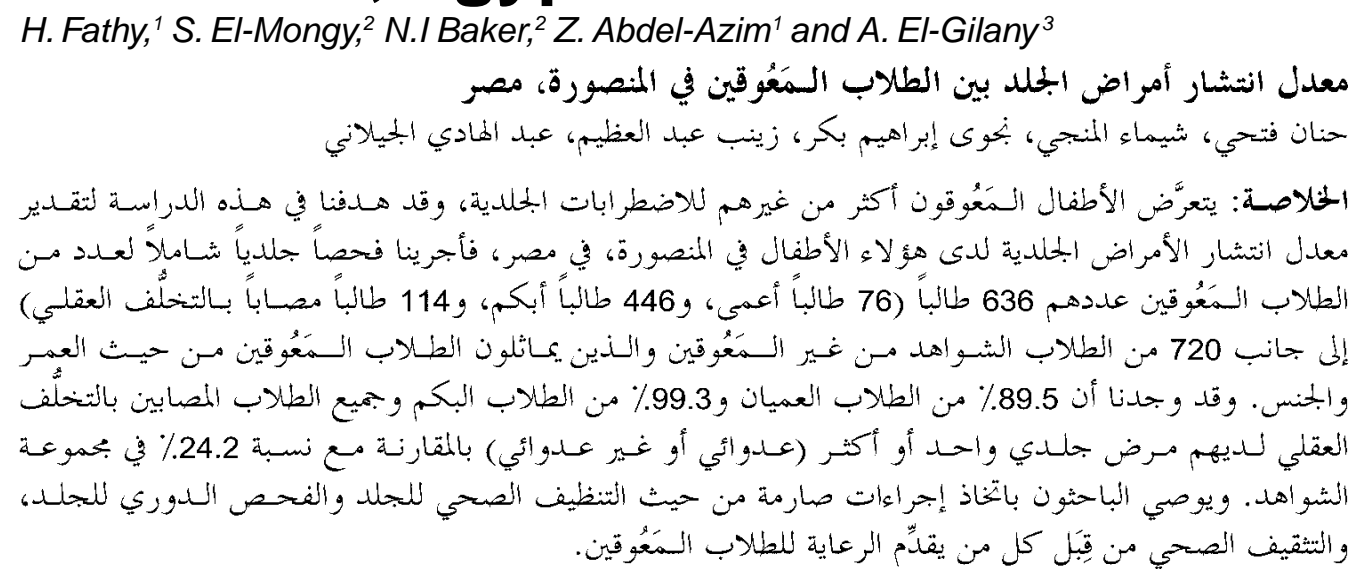

ABSTRACT Children with disabilities may be particularly susceptible to skin disorders, therefore the aim of this study was to estimate the prevalence of skin disease among such children in Mansoura, Egypt. A total of 636 students with disabilities ( 76 blind, 446 deaf-mute and 114 mentally retarded) and 720 sex and age matched students (control) who did not have these disabilities were given a thorough dermatological examination. We found $89.5 \%$ of blind students, $99.3 \%$ of deaf students and $100 \%$ of mentally retarded students had 1 or more skin diseases (both infectious and non-infectious) in comparison to $24.2 \%$ of the control group. Strict hygienic measures, periodic skin examination and health education of persons caring for students with disabilities are recommended.

Prévalence des maladies cutanées chez des élèves handicapés à Mansoura (Egypte)

RESUME Les enfants handicapés peuvent être particulièrement vulnérables aux maladies cutanées ; le but de cette étude était donc d'estimer la prévalence des maladies cutanées chez ces enfants à Mansoura (Egypte). Au total, 636 élèves handicapés (76 aveugles, 446 sourds-muets et 114 arriérés mentaux) et 720 élèves appariés selon le sexe et l'âge (témoins) qui n'avaient pas ces handicaps ont subi un examen dermatologique complet. Nous avons constaté que $89,5 \%$ des élèves aveugles, $99,3 \%$ des élèves sourds et $100 \%$ des élèves arriérés mentaux avaient une ou plusieurs maladies cutanées (infectieuses ou non infectieuses) contre $24,2 \%$ des élèves du groupe témoin. Des mesures d'hygiène rigoureuses, un examen dermatologique périodique et l'éducation sanitaire des personnes qui s'occupent des élèves handicapés sont recommandés.

${ }^{1}$ Department of Dermatology, Venerology and Andrology; ${ }^{3}$ Department of Community Medicine, Faculty of Medicine, University of Mansoura, Mansoura, Egypt.

2University Students' Hospital, University of Mansoura, Mansoura, Egypt.

Received: 20/08/02; accepted: 01/07/03

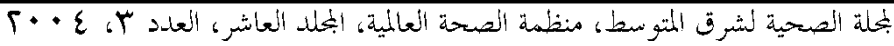




\section{Introduction}

Skin is the mirror of the body. Skin problems are considered upsetting, especially by schoolchildren, and are the cause of much distress. Children with disabilities may be particularly susceptible to skin disorders, sometimes as a direct consequence of their disability owing to limitations preventing them from undertaking the normal care and hygiene of the skin or because of lack of personal and environmental awareness in children with mental retardation. All of these may predispose to a number of skin problems that can add to the child's distress, both physically, due to scratching, itching and pain, and emotionally, due to embarrassment [1].

This study aimed to determine the magnitude and types of skin problems among blind, deaf-mute and mentally retarded school students in Mansoura, Egypt, and to compare the prevalence of these problems with students who do not have these disabilities.

\section{Methods}

This was a case-control study carried out in Mansoura, Egypt during the period 15 September to 15 November 2001 . The study group comprised all students enrolled in 3 institutions caring for blind, deaf-mute and mentally retarded students. Al-Noor institution for blind children and Al-Amal institution for deaf-mute children take students of both sexes provided there is no other disabling condition. Both institutions provide the 3 educational levels of primary (8 years for deaf-mutes), preparatory and secondary schools. The school for mentally retarded students provides a rehabilitation programme according to the intelligence level of the child, regardless of chronological age. Al-Noor and Al-Amal institutions provide boarding for many of their students.

A total of 636 students were examined, 76 who were blind, 446 deaf-mute and 114 mentally retarded. A group of 720 sex and age matched students was selected from nearby urban and rural public schools as the control group. A systematic, random sample of students from different educational grades was selected from 3 schools, 2 urban and 1 rural, from each educational level. The target number was intended to be equal to the total number of students in the test group and comparable regarding age, sex and usual residence of their families.

Visits were carried out to each school on mutually agreed days. A questionnaire was completed for each student with the help of teachers, social workers and nurses. Each student, both cases and controls, was given a thorough dermatological examination of skin, hair and nails. Verbal consent for this examination was obtained from students themselves after approval by the responsible authorities. The diagnosis of skin disease and any associated syndromes was made mainly on clinical examination.

Data was analysed using SPSS, version 9.5. Chi-squared or Fisher exact test was used to test significance between groups, as appropriate; $P \leq 0.05$ was considered statistically significant.

\section{Results}

The mentally retarded students were significantly younger than the blind and deafmute students we studied $\left(\chi^{2}=26.4\right.$, $P \leq 0.001)$. No boarding is provided for the mentally retarded students. The majority of blind students, $78.9 \%$, were boarding compared to $21.5 \%$ of the deaf-mute students $\left(\chi^{2}=160.8, P \leq 0.001\right)$. About two-thirds

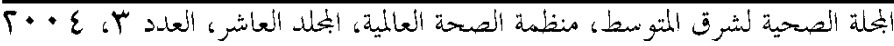


$(63.2 \%)$ of the mentally retarded were male compared to $43.4 \%$ of blind and $51.6 \%$ deaf-mute students $\left(\chi^{2}=7.9 P \leq 0.05\right)$. Regarding the onset of disability, $100 \%$ of mentally retarded, $86.1 \%$ of deaf-mute and $64.5 \%$ of blind students were born with their disability $\left(\chi^{2}=47.8 P \leq 0.001\right)$ (Table $1)$.

Of the mentally retarded students, 40 (35.1\%) showed the clinical criteria of Down syndrome and 2 students showed the clinical criteria of neurofibromatosis type 1 .

Table 2 shows that $89.5 \%$ of the blind, $99.3 \%$ of the deaf - mute and $100 \%$ of the mentally retarded students had 1 or more skin diseases compared to $24.2 \%$ of the control students. This difference was statistically significant. Also, $59.2 \%$ of the blind, $65.5 \%$ of the deaf-mute and $78.9 \%$ of the mentally retarded students had 1 or more infectious skin diseases compared to
$11.4 \%$ of the control students, with the difference statistically significant. A similar situation was observed regarding noninfectious skin diseases.

All types of infectious skin disease, bacterial, parasitic, fungal and viral, were more prevalent among each group of students with disabilities than in the control group of students without these disabilities (Table 3).

Traumatic scars and abrasions, xerosis and hyperkeratosis of the skin, papular urticaria, eczema, postinflammatory hypopigmentation and hyperpigmentation, onychogryphosis and haematoma under the nail were all significantly more prevalent among each test group of students in comparison to the control group (Table 4).

Keratosis pilaris was more prevalent among children who were deaf-mute. Pityriasis alba, angular stomatitis and lightening of hair colour were more prevalent

\begin{tabular}{|c|c|c|c|c|c|c|c|}
\hline \multirow[t]{2}{*}{ Characteristic } & \multicolumn{2}{|c|}{$\begin{array}{l}\text { Blind } \\
(n=76)\end{array}$} & \multicolumn{4}{|c|}{$\begin{array}{c}\text { Deaf-mute } \text { Mentally retarded } \\
(n=446) \quad(n=114)\end{array}$} & \multirow[t]{2}{*}{$\begin{array}{c}\text { Significance } \\
\text { test }\end{array}$} \\
\hline & No. & $\%$ & No. & $\%$ & No. & $\%$ & \\
\hline \multicolumn{8}{|l|}{ Age (years) } \\
\hline $5-9$ & 17 & 22.4 & 77 & 17.3 & 40 & 35.1 & $\chi^{2}=26.4, P \leq 0.001$ \\
\hline $10-14$ & 37 & 48.7 & 194 & 43.5 & 53 & 46.5 & \\
\hline $15+$ & 22 & 28.9 & 175 & 39.2 & 21 & 18.3 & \\
\hline \multicolumn{8}{|l|}{ Sex } \\
\hline Male & 33 & 43.4 & 230 & 51.6 & 72 & 63.2 & $\chi^{2}=7.9, P \leq 0.05$ \\
\hline Female & 43 & 56.6 & 216 & 48.4 & 42 & 36.8 & \\
\hline \multicolumn{8}{|l|}{ Residence } \\
\hline Institute & 60 & 78.9 & 96 & 21.5 & 0 & - & $\chi^{2}=160.8, P \leq 0.001$ \\
\hline Home & 16 & 21.1 & 350 & 78.5 & 114 & 100 & \\
\hline \multicolumn{8}{|l|}{ Onset of disability } \\
\hline Congenital & 49 & 64.5 & 384 & 86.1 & 114 & 100 & $\chi^{2}=47.8, P \leq 0.001$ \\
\hline After birth & 27 & 35.5 & 62 & 13.9 & 0 & - & \\
\hline Post-infection & 16 & 21.1 & 60 & 13.5 & - & - & \\
\hline Post-accident & 3 & 3.9 & 0 & - & - & - & \\
\hline Post-surgery & 8 & 10.5 & 2 & 0.4 & - & - & \\
\hline
\end{tabular}

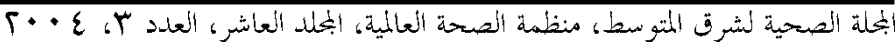




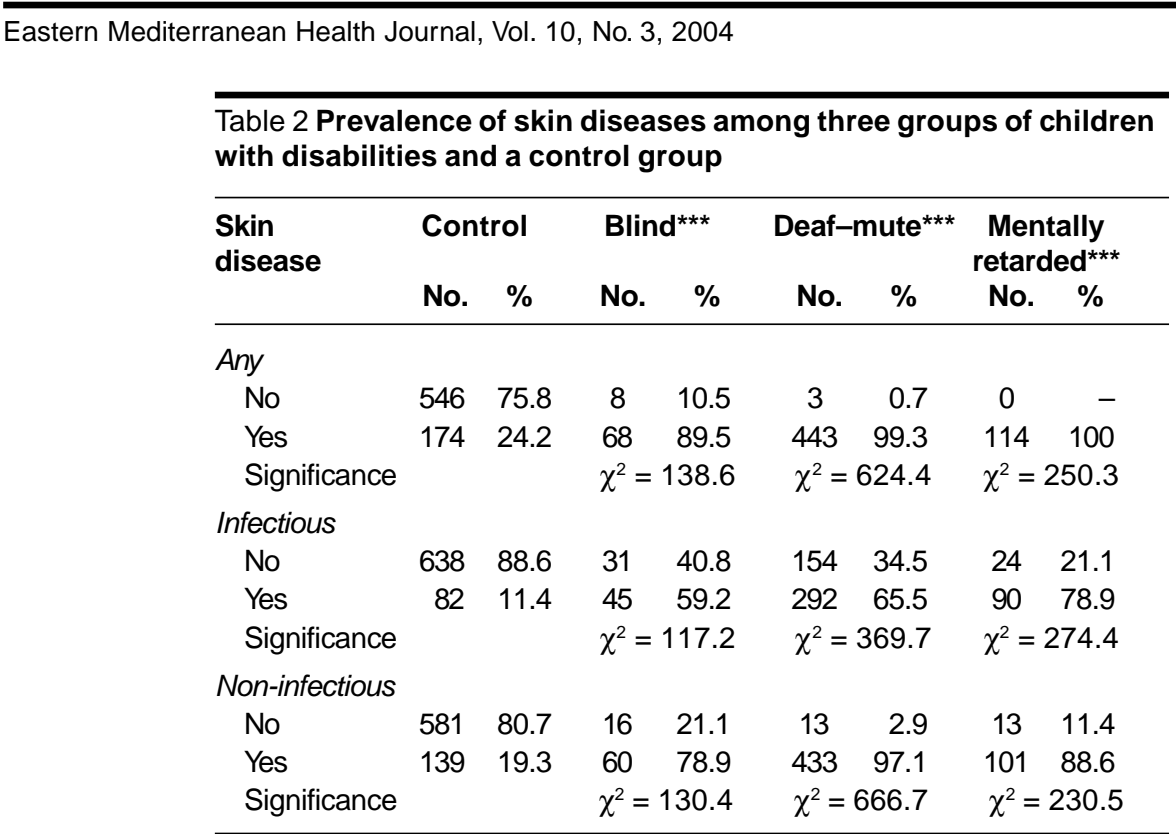

${ }^{* * * P} \leq 0.001$.

\begin{tabular}{|c|c|c|c|c|c|c|c|c|}
\hline \multirow[t]{2}{*}{$\begin{array}{l}\text { Infectious } \\
\text { skin disease }\end{array}$} & \multicolumn{2}{|c|}{ Control } & \multicolumn{2}{|c|}{ Blind } & \multicolumn{2}{|c|}{ Deaf-mute } & \multicolumn{2}{|c|}{$\begin{array}{l}\text { Mentally } \\
\text { retarded }\end{array}$} \\
\hline & No. & $\%$ & No. & $\%$ & No. & $\%$ & No. & $\%$ \\
\hline Bacterial & 6 & 0.8 & 8 & $10.5^{\star * \star}$ & 61 & $13.7^{\star \star \star}$ & 30 & $26.3^{* * *}$ \\
\hline Impetigo & 5 & 0.7 & 5 & $6.6^{\star \star \star}$ & 26 & $5.8^{\star \star \star}$ & 23 & $20.2^{\star \star *}$ \\
\hline Boils \& folliculitis & 1 & 0.1 & 3 & $3.9^{\star *}$ & 36 & $8.1^{\star \star \star}$ & 8 & $7.0^{\star \star \star}$ \\
\hline Parasitic & 66 & 9.2 & 34 & $44.7^{\star * \star}$ & 227 & $50.9^{\star \star \star}$ & 62 & $54.4^{\star * *}$ \\
\hline Pediculosis capitis & 65 & 9.0 & 34 & $44.7^{\star \star \star}$ & 227 & $50.9^{\star \star \star}$ & 62 & $54.4^{* * *}$ \\
\hline Scabies & 1 & 0.1 & 0 & 0 & 1 & 0.2 & 2 & $1.8^{*}$ \\
\hline Fungal & 10 & 1.4 & 15 & $17.9^{\star \star \star}$ & 49 & $11.0^{\star \star \star}$ & 15 & $13.2^{\star * *}$ \\
\hline Tinea capitis & 0 & - & 0 & - & 7 & $1.6^{\star \star}$ & 6 & $5.3^{\star \star \star}$ \\
\hline Tinea versicolor & 2 & 0.3 & 0 & - & 9 & $2.0^{\star \star \star}$ & 3 & $2.6^{\star \star \star}$ \\
\hline Tinea pedis & 5 & 0.7 & 11 & $14.5^{\star \star \star}$ & 28 & $6.3^{\star \star \star}$ & 7 & $6.1^{\star \star \star}$ \\
\hline Onychomycosis & 3 & 0.4 & 6 & $7.9^{\star \star \star}$ & 6 & 1.3 & 5 & $4.4^{\star \star \star}$ \\
\hline Tinea circinata & 0 & - & 0 & - & 5 & $1.1^{\star *}$ & 2 & $1.8^{*}$ \\
\hline Viral & 3 & 0.4 & 5 & $6.6^{\star \star \star}$ & 14 & $3.1^{\star \star \star}$ & 7 & $6.1^{\text {***}}$ \\
\hline Wart & 1 & 0.1 & 3 & $3.9^{\star \star}$ & 9 & $2.0^{\star \star \star}$ & 4 & $3.5^{\star \star \star}$ \\
\hline Herpes simplex & 1 & 0.1 & 2 & $2.6^{\star}$ & 5 & $1.1^{*}$ & 2 & $1.8^{*}$ \\
\hline Chicken pox & 1 & 0.1 & 0 & - & 0 & - & 1 & 0.9 \\
\hline
\end{tabular}

${ }^{*} \mathrm{P} \leq 0.05,{ }^{* *} \mathrm{P} \leq 0.01,{ }^{* * *} \mathrm{P} \leq 0.001$.

a Some students were simultaneously affected by $>1$ infection of the same group.

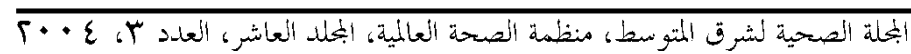




\begin{tabular}{|c|c|c|c|c|c|c|c|c|}
\hline \multirow[t]{2}{*}{$\begin{array}{l}\text { Non-infectious } \\
\text { skin disease }\end{array}$} & \multicolumn{2}{|c|}{ Control } & \multicolumn{2}{|c|}{ Blind } & \multicolumn{2}{|c|}{ Deaf-mute } & \multicolumn{2}{|c|}{$\begin{array}{l}\text { Mentally } \\
\text { retarded }\end{array}$} \\
\hline & No. & $\%$ & No. & $\%$ & No. & $\%$ & No. & $\%$ \\
\hline $\begin{array}{l}\text { Traumatic scar \& } \\
\text { abrasion }\end{array}$ & 30 & 4.2 & 31 & $40.8^{\star \star \star}$ & 267 & $59.9^{\star \star \star}$ & 50 & $43.9^{\star \star \star}$ \\
\hline Acne vulgaris & 80 & 11.1 & 12 & 15.8 & 60 & 13.5 & 12 & 10.5 \\
\hline Hyperkeratosis & 12 & 1.7 & 11 & $14.5^{\star \star \star}$ & 136 & $30.5^{\star \star \star}$ & 17 & $14.9^{\star \star \star}$ \\
\hline Xerosis & 2 & 0.3 & 12 & $15.8^{* \star *}$ & 59 & $13.2^{\star * \star}$ & 20 & $17.5^{\star \star *}$ \\
\hline Keratosis pilaris & 2 & 0.3 & 0 & - & 41 & $9.2^{\star \star \star}$ & 2 & 1.8 \\
\hline Miliaria rubra & 86 & 11.9 & 14 & 18.4 & 37 & 8.3 & 18 & 15.8 \\
\hline Pityriasis alba & 13 & 1.8 & 3 & 3.9 & 60 & $13.5^{\star \star \star}$ & 12 & $10.5^{\star \star *}$ \\
\hline Angular stomatitis & 0 & - & 0 & - & 6 & $1.3^{* *}$ & 14 & $14.3^{\star \star \star}$ \\
\hline $\begin{array}{l}\text { Frictional lichenoid } \\
\text { papules }\end{array}$ & 4 & 0.6 & 2 & 2.6 & 3 & 0.7 & 0 & - \\
\hline Papular urticaria & 5 & 0.7 & 4 & $5.3^{\star *}$ & 51 & $11.4^{\star \star \star}$ & 7 & $6.1^{\star \star *}$ \\
\hline Eczema & 1 & 0.1 & 6 & $7.9^{\star \star \star}$ & 25 & $5.6^{\star \star \star}$ & 5 & $4.4^{\star \star \star}$ \\
\hline Melanocytic naevi & 31 & 4.3 & 7 & $9.2^{*}$ & 35 & $7.8^{\star *}$ & 4 & 3.5 \\
\hline Freckle & 18 & 2.5 & 2 & 2.6 & 23 & $5.2^{*}$ & 0 & - \\
\hline $\begin{array}{l}\text { Post-inflammatory } \\
\text { hyperpigmentation }\end{array}$ & 1 & 0.1 & 7 & $9.2^{\star \star \star}$ & 39 & $8.7^{\star \star \star}$ & 4 & $3.5^{\star \star \star}$ \\
\hline $\begin{array}{l}\text { Post-inflammatory } \\
\text { hypopigmentation }\end{array}$ & 7 & 0.9 & 14 & $18.4^{\star \star \star}$ & 44 & $9.9^{\star \star \star}$ & 4 & $3.5^{\star}$ \\
\hline Café au lait & 7 & 0.9 & 1 & 1.3 & 4 & 0.9 & 2 & 1.8 \\
\hline Vitiligo & 0 & - & 0 & - & 2 & 0.4 & 1 & 0.9 \\
\hline Cicatricial alopecia & 2 & 0.3 & 3 & $3.9^{*}$ & 5 & 1.1 & 1 & 0.9 \\
\hline Dandruff & 9 & 1.3 & 2 & 2.6 & 11 & 2.5 & 4 & 3.5 \\
\hline Alopecia areata & 0 & - & 4 & $5.3^{\star \star \star}$ & 5 & $1.1^{\star *}$ & 1 & 0.9 \\
\hline Hair colour change & 1 & 0.1 & 1 & 1.3 & 6 & $1.3^{*}$ & 4 & $3.5^{\star \star \star}$ \\
\hline Leukonychia & 6 & 0.8 & 5 & $6.6^{\star \star *}$ & 134 & $30.0^{* * *}$ & 29 & $25.4^{\star \star *}$ \\
\hline Nail trauma ${ }^{b}$ & 0 & - & 5 & $6.6^{\star \star \star}$ & 30 & $6.7^{\star \star \star}$ & 6 & $5.3^{\star * *}$ \\
\hline Nail clubbing & 0 & - & 0 & - & 4 & $0.9^{*}$ & 0 & - \\
\hline Others & 2 & 0.2 & 2 & 2.6 & 12 & 2.6 & 3 & 2.6 \\
\hline
\end{tabular}

${ }^{*} \mathrm{P} \leq 0.05,{ }^{* *} \mathrm{P} \leq 0.01,{ }^{* * *} \mathrm{P} \leq 0.001$.

a Some students were simultaneously affected by $>1$ non-infectious skin disease.

${ }^{b}$ Includes onychogryphosis and haematoma under the nail.

among deaf-mute and mentally retarded students. Alopecia areata was prevalent among blind and deaf-mute students but was not recorded in the children in the control group. Cicatricial alopecia was significantly more prevalent among blind students

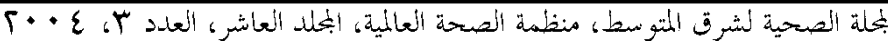


than among students in the other groups (Table 4).

The following skin diseases were observed as sporadic cases: benign skin tumour (4 in the deaf-mute group), haemangioma ( 3 in the deaf-mute group, 1 in the mentally retarded group), pseudoacanthosis nigricans (1 in each of the control group, the blind group and the deaf-mute group), neurofibromatosis ( 2 in the mentally retarded group), Waardenburg syndrome ( 1 in the deaf-mute group), skin tags ( 1 in the deaf-mute group and 1 in the control group), albinism (1 in the blind group), psoriasis, lichen planus and varicose vein ( 1 in the deaf-mute group for each condition).

\section{Discussion}

The type and prevalence of disease in any community reflects the genetic and racial constitution of its members, their nutritional status, and social and hygiene standards. Incidence of disease is affected directly and indirectly by the climate, and is influenced by the quality and quantity of medical care [2]. School students are an important sector of any community, so they are subjects of special consideration as they are of vital importance to the health of the community. Children with disabilities are a vulnerable sector of the community with some specific problems.

In this study we found that the overall prevalence of skin disease was significantly higher in the children in each test group compared to the children in the control group.

We classified skin diseases into infectious and non-infectious. A significantly high prevalence of infectious skin disease was observed for each test group compared to the control group. Similar findings have been reported among students with disabilities in Saudi Arabia [3]. The high prevalence of infectious skin diseases we found might be due to poor personal hygiene, or perhaps to low standard of living. The higher prevalence found among mentally retarded students might be attributed to the low level of awareness in this group. Additionally, skin lesions that would annoy people who are not mentally retarded may often go unnoticed.

In this study, the prevalence of bacterial skin disease was significantly higher among each of the test groups in comparison with the control group. This may be attributed to the habit of touching and scratching different parts of the skin, often seen in such groups. This habit may facilitate the spread of bacterial infections. Also, scratching of individual lesions, e.g. impetigo or folliculitis, may contribute to the spread of infection to other students. A higher percentage of bacterial infections were detected in the children who were mentally retarded. This is in agreement with the findings of others [4] who suggest that low resistance may be responsible for pyogenic skin infection among mentally retarded people. Also, we suggest that it may be due to self-injurious behaviour, which is we have often observed among mentally retarded students.

As regards parasitic skin infections, pediculosis capitis (head lice) was the most prevalent infectious skin disease encountered in the test groups of students, and was significantly higher than in the control group. A high prevalence of pediculosis capitis has previously been reported among mentally retarded students in Alexandria [5]. In contrast to our findings, a low prevalence of pediculosis capitis was reported among blind and deaf-mute students in Saudi Arabia [3]. This can be explained by the difference in sex ratio: their study included only males. However, in our study,

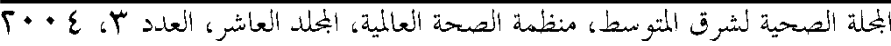


females accounted for more than twofifths of the cases. It has been found that head lice are more common among females than males [6]. Scabies was detected in 2 mentally retarded students, statistically significantly higher than the control group.

Fungal infections were significantly higher in children in each test group compared to the control group. Tinea pedis was the most frequent infection among the groups examined. Tinea pedis and onychomycosis were more prevalent in blind students. This may be because most of these students $(78.9 \%)$ live in the institution, where washing facilities are shared, increasing the chance of infection. Also, we observed that the blind children were wearing heavier footwear to protect them against trauma, and that may increase the chance of contracting tinea pedis.

We found a high prevalence of viral infection in the test groups compared to the control group. Warts were the most prevalent viral infection. Our results were in agreement with the findings of a study on blind and deaf students in Saudi Arabia [3].

In our study, the prevalence of noninfectious skin disease among blind, deafmute and mentally retarded students was significantly higher than in the control group. Both the nature of the disability and the associated day-to-day problems may explain these high rates. For example, the high rate of traumatic scars detected among the deaf-mute students we examined may be explained by playing football, which is a common recreation [7] that predisposes them to outdoor accidents and consequent trauma. With mentally retarded students, these scars may be a result of aggressive behaviour when angry, which may predispose the children to accidents and consequent trauma. Self-injurious behaviour is a serious problem that is not uncommon among individuals with mental retardation and could explain these traumatic scars. It has been reported that physical injury such as excoriation, scar, callus formation, haematomas and local infections are common among children with disabilities [8]. Traumatic scars among blind students could be attributed to difficulty in mobility, making them prone to indoor accidents and trauma [7].

Prevalence of localized hyperkeratosis was significantly higher in all the test groups compared to the control group. In a previous study, high prevalence of hyperkeratosis and roughness of the skin among mentally retarded students was observed [5]. Multiple traumas and the habit of touching the skin continuously may predispose to this condition. Also, hyperkeratosis may reflect the presence of Down syndrome in mentally retarded students [9]. There were 40 such children in the group we studied.

Xerosis, pityriasis alba, angular stomatitis and follicular hyperkeratosis (keratosis pilaris) were all observed at higher rates among the test groups in our study compared to the control group. Such diseases may reflect nutritional deficiency. Multiple vitamin deficiency may predispose to these symptoms and may reflect negligence of the staff in the institutions where those handicapped students are resident or it may reflect their low socioeconomic standard. Also, xerosis may be one of the criteria of Down syndrome, as reported by others $[5,10]$.

Pityriasis alba was more prevalent among the deaf-mute students. This could be attributed to the frequent exposure of these students when playing football to sunlight and cold winds, leading to excessive dry skin, which predisposes to this condition.

We found the prevalence of eczema (atopic dermatitis, contact dermatitis, ecze-

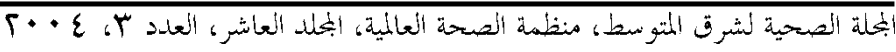


ma of the hand) was significantly higher among the children with disabilities in comparison to the children in the control group. Contact with irritant as soap and detergents without risk perception may play a role in increasing the frequency of eczema among students who have disabilities. Additionally, the observed dry skin among this group, frequent trauma and scratching the skin are all factors which may aggravate eczema. Also, many are unduly susceptible to stress, which is another aggravating factor.

We found that the prevalence of papular urticaria was significantly higher among each group of the handicapped in comparison to the control. This may be attributed to the children being unaware of the antecedent bite as some students may not see or hear the insect. Also, many blind and deaf-mute students live in the institutions, with shared bedrooms where they are exposed to insects. Furthermore, mentally retarded students may hold or come in contact with infected pet animals that increase the chance of infestation by fleas and mites.

Many hair changes were detected among the students in the test groups. Alopecia areata was significantly higher among blind and deaf-mute students in comparison to the control group. This may be attributed to stressful life events in these groups. Cicatricial alopecia was significantly higher among blind students than students in the control group. This may be attributed to a greater exposure to trauma and accidents. Scars from previous operations for brain tumours which were found among some blind students may be another explanation. Change in hair colour was detected in $1.3 \%$ of deaf-mute students and among $3.5 \%$ of mentally retarded students. These may be associated with the syndromes of deafness, such as Waardenburg syndrome (1 case). Also, in Down syn- drome (40 cases), the hair is often hypopigmented [11].

Only 1 case of Waardenburg syndrome was detected among the deaf-mutes. This syndrome is characterized by deafness and pigmentary disorders of the eyes, hair and skin. In a study from South Africa, Waardenburg syndrome was detected among $2.7 \%$ of deaf students [12]. This difference might be attributed to racial factors.

Nail changes in the form of leukonychia were significantly more prevalent among the students who had disabilities in comparison to the control group. It was most prevalent among deaf-mute students. This condition may be congenital or acquired. It has been reported that total leukonychia may be associated with deafness [13]. Frequent trauma may explain the high prevalence of leukonychia among students who have mental or physical disabilities.

Traumatic nail changes were found among $6.6 \%$ of blind students, $6.7 \%$ of deaf-mute students and $5.3 \%$ of mentally retarded students. This is in agreement with the findings of Ismail et al. (1997) who reported nail changes among $6.8 \%$ of mentally retarded students [5].

\section{Conclusions}

We conclude that in the population we studied there was high prevalence of infectious and non-infectious skin disease in each group in comparison with the control group. This may reflect some negligence and poor personal hygiene in some students. Although these handicapped students were covered by the school health insurance programme, it seems that the care provided was inadequate. Because of the higher prevalence of skin conditions, school doctors and nurses need dermato-

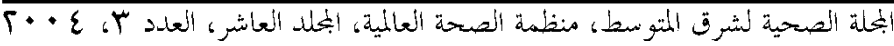


logic training. Periodic skin examination is of vital importance for all people with disabilities to reach a proper diagnosis and to offer treatment. Health education for teachers and parents on sound personal hygiene and clean environment is recommended.

\section{References}

1. Greaves MW. Dermatology. Practitioner, 1976, 217:585-90.

2. Burton JI, Savin JA, Champion RH. Introduction, epidemiology and historical bibliography. In: Champion $\mathrm{RH}$, Burton JL, Ebling FJG, eds. Textbook of dermatology, 5th ed. Oxford, Blackwell Scientific Publications, 1992, Vol. 1:1-15.

3. Abolfotouh MA, Bahamdan K. Skin disorders among blind and deaf male students in southwestern Saudi Arabia. Annals of Saudi medicine, 2000, 20(2): 161-4.

4. Cotterill JA, Millard LG. Psychocutaneous disorders. In: Champion $\mathrm{RH}$, Burton JL, Burns A.D, eds. Textbook of dermatology, 6th ed. Oxford, Blackwell Scientific Publications, 1998, Vol. 3: 2785-97.

5. Ismail EA et al. Skin change in the mentally retarded children in Alexandria. Journal of the Pan-Arab League of Dermatologists, 1997; 8(2):115.

6. Elgart ML. Pediculosis. Dermatologic clinics, 1990, 8(2)219-28.

7. Abolfotouh MA, Telmesani A. A study of some psycho-social characteristics of blind and deaf male students in Abha City, Asir Region, Saudi Arabia. Public health, 1993, 107(4):261-9.

8. Hyman $\mathrm{SI}$ et al. Children with self-injurious behavior. Pediatrics, 1990, 85(3): 437-41.

9. Brugge $\mathrm{KL}$ et al. Evidence for accelerated skin wrinkling among developmentally delayed individuals with Down's syndrome. Mechanisms of ageing and development, 1993, 70(3):213-25.

10. Scherbenske JM et al. Cutaneous and ocular manifestations of Down's syndrome. Journal of the American Academy of Dermatology, 1990, 22(5):933-8.

11. Carter DM, Jegasothy BV. Alopecia areata and Down syndrome. Archives of dermatology, 1976, 112(10):1397-9.

12. Beighton $P$ et al. Hearing impairment and pigmentary disturbance. Annals of the New York Academy of Science, 1991, 630:152-66.

13. Dawb RPR, Baran R. Disorders of nails. In: Champion RH, Burton JL, Ebling FJG, eds. Textbook of dermatology, 5th ed. Oxford, Blackwell Scientific Publications, 1992, Vol. 3:2511. 